picture of the fission process, introducing the term 'fission' and making an estimate of the energy liber?tion. Using the method of recoil, which she and Hahn had applied so effectively in the early days of radioactivity, she was later able to show that the bodies previously called 'transuranic' did, in fact, originate by fission. Since 1939, Dr. Meitner has worked in Stockholm, where she now directs a small but active Iaboratory. Enjoying good health and abundant energy she can, while looking back on a life full of high achievement, also look forward to further years of happiness and success.

\section{Nobel Prize for Medicine :}

Dr. Paul Müller

The award of the Nobel Prize for Medicine for 1948 has been made to Dr. Paul Müller for his discovery of the effects as an insecticide of D.D.T. Drs. P. Läuger, P. Müller and H. Martin were the leaders of an intensive research for insecticidal chemicals in the Basle laboratories of J. R. Geigy, S.A., which extended more than twenty years. The researches were directed originally towards the discovery of mothproofing agents to be incorporated in fabrics. It was in the section of research entrusted to Paul Müller that D.D.T. was actually synthesized and its contact insecticidal properties discovered. It seems to have been in the course of field trials that its remarkable effectiveness against the Colorado beetle was noticed. It was soon found to be equally toxic to the louse and the mosquito. The material was brought to the notice of medical entomologists in Great Britain and the United States at a critical moment in the War when the supplies of pyrethrum were rapidly falling short of the demand. Soon it was being produced in very large quantities on both sides of the Atlantic. It proved of enormous value in combating typhus and malaria during the War, and now it is being employed with success in campaigns for the complete eradication of malaria from island areas. It is an equally valuable weapon in agricultural entomology and has provided a great stimulus to the search for yet other insecticides.

\section{Dr. G. M. Vevers}

DR. G. M. Vevers, superintendent of the Zoological Society of London, will be retiring for medical reasons at the end of the year. He received his medical education at St. Thomas's Hospital, London, and served in the First World War as a captain in the R.A.M.C. After demobilization he became assistant to Prof. R. T. Leiper, in the Department of Helminthology of the London School of Tropical Medicine, and was awarded a Beit Medical Fellowship for Medical Research in parasitology. The same year he was also appointed honorary parasitologist to the Zoological Society and spent much of his time in the Society's prosectorium. In 1921 he went to British Guiana on a Colonial Office inquiry into filariasis. In $1923 \mathrm{Dr}$. Vevers was appointed superintendent of the Zoological Society in succession to the late R. I. Pocock. He introduced the application of the general principles of hygiene to wild animals in captivity, paying particular attention to the helm. inthic infections which used to be such a frequent cause of death in newly imported animals. He also introduced improvements in diet and housing, resulting in a reduction of the incidence of dietetic diseases and epidemies such as tuberculosis. He was also responsible for carrying out the extensive building programme at the Zoological Gardens, Regent's Park, following the First World War.
Dr. Vevers was closely associated with the late Sir Peter Chalmers Mitchell in the formation and development of Whipsnade Zoological Park, in which he took a very special interest. $\mathrm{He}$ also designed the layout of the Dudley Zoological Gardens, and since the Second World War has been engaged in the reconstruction and rehabilitation of the $Z_{00}$ at Regent's Park. He is the author of numerous papers on helminthology and the keeping and breeding of animals in captivity ; also children's books and other books on general natural history, and has been a regular broadcaster in the B.B.C. Children's Hour and other programmes. He was elected an honorary fellow of the Royal College of Surgeons in 1946; and has been awarded the Silver Medal of the Zoological Society of London, and the Gold Medal of the Zoological Society of Glasgow and West of Scotland. After his retirement Dr. Vevers will continue to reside at Whipsnade, and will be available for consultation by the Society in an advisory capacity.

\section{Botany at Rothamsted:}

Dr. Winifred E. Brenchley

ON her retirement from the post of head of the Botany Department, Rothamsted Experimental Station, on October 1, Dr. Winifred E. Brenchley had completed forty-two years of service there. She went to Rothamsted in 1906 as the holder of a Gilchrist Studentship of the University of London, and in the following year was appointed to the permanent staff. Dr. Brenchley was the first woman member of the staff, and it says much for her personality and for the quality of her work that the appointment was an immediate success and paved the way for many other women to undertake research in agricultural science at Rothamsted. Dr. Brenchley was a pioneer in the study of the effects of micronutrient elements on plant growth, and is an acknowledged authority in this field. Before the importance of elements such as boron, copper and manganese in plant nutrition was fully appreciated, she began a long series of solution-culture studies on elements other than the ten known to be essential. Her monograph "Inorganic Plant Poisons and Stimulants", published in 1914, described her own results and provided a valuable critical summary of the scattered information then existing on the subject. The investigation of the effects of boron made afterwards is perhaps the best-known work from her laboratory. Dr. Brenchley's other chief interests have been in the ecology of weeds, and in the changes with time in the flora of the permanent Park Grass plots at Rothamsted. The results of her earlier studies on these plots provided material for her book "Manuring of Grassland for Hay", published in 1924. Dr. Brenchley has played a very active part in the social life of Rothamsted, and in recognition of her long-continued interest in the welfare of all members of the staff, a presentation was made to her at a party held on October 22, attended by many of her past and present colleagues. Dr. Brenchley is to continue her research work at Rothamsted on a part-time basis. Her successor as head of the Botany Department is Dr. D. J. Watson, formerly in eharge of the Crop Physiology Section, which has now been merged with the Botany Department.

\section{Indian Arch æology at the University of London}

ON October 28, at the Institute of Archæology, London, Prof. K. deB. Codrington, the newly appointed professor of Indian archæology, gave an in- 
augural lecture entitled "The Place of Archæology in Indian Studies". The High Commissioner for India, Mr. Krishna Menon, who took the chair, said that the creation of such a chair was very welcome and he hoped that it would lead to exchanges of scholars on both sides. He welcomed the appointment of Prof. Codrington, whose second home was India. In his lecture, Prof. Codrington stressed the educational value of the study of archæology, and the need of close collaboration between all who are interested in the study of India. Outlining the relations of the earliest city culture in India with north and south Persia, he went on to describe the intrusion of the neolithic tanged-adze culture of South-East Asia with reference to the first appearance of the Aryans in India. The chair of Indian archæology in the University of London is held jointly at the Institute of Archæology and the School of Oriental Studies.

\section{Food and Agriculture Organisation}

THE fourth annual conference of the Food and Agriculture Organisation of the United Nations will open in Washington on November 15. The conference will review the world food situation and the technical activities of the Food and Agriculture Organisation. It will also consider major constitutional, administrative and financial issues, particularly the budget for the next financial year. The United Kingdom delegation will be led by Mr. Tom Williams, Minister of Agriculture and Fisheries; the alternate leader is Mr. R. H. Franklin, deputy secretary in the Ministry of Agriculture and Fisheries. Among other members of the delegation will be Sir Ralph Enfield (chief economic adviser) and Mr. A. T. A. Dobson (fisheries adviser), both of the Ministry of Agriculture and Fisheries; Dr. N. C. Wright (chief scientific adviser), of the Ministry of Food; Sir Gerard Clauson, assistant under-secretary of State in the Colonial Office; Mr. P. N. R. Butcher, assistant secretary in the Ministry of Health; Mr. A. N. Duckham, agricultural attaché to the British Embassy; and Mr. G. R. Oake, head of the British Supply Office (Food) in Washington. In addition, Mr. James Turner, president of the National Farmers Union, and Mr. E. G. Gooch, president of the National Union of Agricultural Workers, will serve as advisers to the delegation.

\section{Biological Service in Great Britain}

Mr. Herbert Morrison, Lord President of the Council, announced in the House of Commons on November 1 that Capt. Cyril Diver has been appointed head of the biological service which is to be formed for the conservation of the fauna and flora of Great Britain, including Nature reserves. The London office of the service is at Thorney House, Smith Square, S.W.1.

\section{Society of Chemical Industry: Fine Chemicals Group}

The Fine Chemicals Group of the Society of Chemical Industry has for its objects "The discussion of fine chemicals especially such as are of therapeutic or biological interest". The Group held its inaugural meeting at the Royal Institution on October 5, with Sir Jack Drummond, chairman of the Group, presiding. Prof. J. H. Burn, professor of pharmacology, University of Oxford, delivered the inaugural address and reviewed much of the important work that has been done in the production of fine chemicals for medicinal use. He recalled the lapse of time between the discovery of penicillin in 1929 and its use in 1941, and suggested that, but for the recog. nition of the curative value of sulphonamides, it is possible that the use of penicillin might have been held up indefinitely owing to the false notion that "an antibacterial agent for use in man is an impossibility". Prof. Burn referred particularly to the work in the fields of tuberculosis and cancerous growths, of which the latter is still, in his opinion, the out. standing unsolved problem; it is one thing to deal with bacteria in the blood and extracellular fluid, but quite another thing when the bacterial agents are inside the cell or even in the nucleus. Much knowledge is to be gained from the classical work of Dale and Laidlaw with Carr, Barger and Ewins on adrenaline (and sympathomimetic amines), histamine and acetylcholine. It is increasingly obvious that the effect of chemical substances in the body is to modify or interfere with the action of these three compounds. This matter is of great importance in the study of anæsthetics, and it would be worth while to promote research in this direction. In the general problems of research, Prof. Burn felt that the university worker ought to pass on more of his knowledge to the industrial laboratories, and the industrial men of science must take 'refresher' courses in the academic laboratories to keep abreast of new techniques. The crying need of to-day is not for more fundamental knowledge but more application of the present existing knowledge. In conjunction with this, Prof. Burn expressed the opinion that the value of elaborating quantitative methods for the estimation of biological properties is indisputable. This work has been criticized as not leading to any fundamental discovery; but since 1926 chemical work has been much facilitated by the introduction of biological standards, and the Pharmaceutical Society has made a wise decision in establishing a laboratory for the study of biological standardization.

\section{Cultural Geography of the Tarascan Area, Mexico}

PuB. No. 7 of the Institute of Social Anthropology, Smithsonian Institution, Washington, by Robert C. West, may be specially welcomed because it deals with a population in its environment in western Mexico, and takes note of physical features, climate, agriculture, handierafts, houses and settlements and material culture generally. The geognostic map is an interesting key to the environment and so are the maps, admittedly based on inadequate data none too reliable, of climatic features, especially the frequency of frost on the highlands. Tarascan was an indigenous language of pre-Spanish days; the conquerors misused the natives in mines and elsewhere, missionaries and others 'hispanized' large numbers of the remainder on great estancias (stock-raising farms) and haciendas (crop farms); so the old language lingers only in the poorer areas which Europeans did not wish to occupy. The recession of Tarascan speech is traced in maps for different periods. Wheat and barley were cultivated soon after the Spanish Conquest in order to pay the tribute demanded by the authorities, and Arabic modes of irrigation also came in. Each community had owned surrounding lands in which the chief apportioned the right of user among the villagers. Since the mid-nineteenth century, individual ownership has developed; but vestiges remain, and in some pueblos a head-of-family may have 2-4 hectares allotted sine die provided he does not leave the land untilled for more than two successive years. He may sell his right-of-user, but only to another 